IJLR: International Journal of Law Recontruction

Volume 4, Number 2, September 2020

DOI : http://dx.doi.org/10.26532/ijlr.v4i2.11319

\title{
THE SETTLEMENT MODEL AGAINST CREDIT AGREEMENTS BETWEEN CREDITORS AND DEBTORS
}

\author{
Anis Mashdurohatun \\ Sultan Agung Islamic University \\ anism@unissula.ac.id \\ Eyrsa Setya Kurnia \\ Sultan Agung Islamic University \\ eyrsasetya01@gmail.com
}

\begin{abstract}
Abstrak
The purpose of this study is to analyze the factors that cause bad credit to credit agreements between creditors and debtors and to formulate a model of bad credit settlement against credit agreements between creditors and debtors. This study uses an empirical juridical approach. This study found that the factors causing the occurrence of bad credit are due to internal factors of the bank (creditors), namely ignoring bank prudential principles, especially the $5 \mathrm{C}$ principle, where banks are less careful in assessing potential debtors, and external factors (debtors), where the debtor's business decreases, debtors are not clever in managing their business, debtors have large debts, credit is not used properly, hidden credit and fictitious credit. The non-performing loan settlement model puts forward the principles of taawun and tawazun, with several stages, namely subpoena, credit restructuring and, / or credit settlement by selling collateral as a last resort.
\end{abstract}

Keywords: Bad Credit; Agreement; Settlement Model.

\section{A. INTRODUCTION}

Economic globalization has had a major impact on the field of law, including banking law ${ }^{1}$. Banks are financial institutions that can provide funds in the form of loans to the public for business development through a credit agreement ${ }^{2}$. A bank that has a strategic position to encourage

1 Anis Mashdurohatun., R. Sidji, Gunarto, and Mahmutarom. Factors Causing Banking Cyber Crime in Indonesian. International Journal of Economic Research 14 (15). 2017. See too Anis Mashdurohatun, Tantangan Ekonomi Syariah dalam Menghadapi Masa Depan Indonesia di Era Globalisasi, Jurnal Dinamika Hukum, Vol. 11 Edisi Khusus Februari 2011, Page.77. see too Anis Mashdurohatun, Problematika Perlindungan Hak Cipta Di Indonesia, Yustisia, Vol.1 No.1 Januari - April 2012. 73 Page.73.

2 Bambang Suprabowo dkk, The Inhibiting Factors On Legal Protection For Recipients Of Fidusiary Warranties With Inventory Guaranted Objects, South East Asia Journal of Contemporary Business, Economics and Law, Vol. 13, Issue 4 (August) ISSN 2289-1560, Page.117, see too Imron Rosyadi, Jaminan Kebendaan Berdasarkan Akad Syariah, Kencana, Jakarta, 2017, Page. 41 
national economic growth, which functions as a financial intermediary. ${ }^{3}$ The bank's activities are expressly regulated in Article 1 number 2 of Law Number 10 of 1998 concerning Amendments to Law Number 7 of 1992 concerning Banking. ${ }^{4}$ Bad credit is a risk of extending bank credit which has a negative impact which, if not resolved, will affect the health level of the financial institution. ${ }^{5}$ So a credit guarantee is needed as a guarantee by the bank as the creditor if the debtor fails to promise or defaults. ${ }^{6}$

One form of collateral can be in the form of immovable objects, namely land and buildings encumbered with Mortgage Rights in accordance with Law Number 4 of 1996 concerning Mortgage Rights for Land and Objects related to Land, hereinafter referred to as UUHT. According to Article 1 paragraph 1 of the UUHT, Mortgage Rights are rights to land and objects related to land which are security rights imposed on land rights as referred to in the Basic Agrarian Law (UUPA). ${ }^{7}$ Mortgage is an accessoary agreement, namely before the imposition of an object, preceded by a debtreceivable agreement between the creditor and the debtor. The debt and receivable agreement states that there is a promise to provide mortgage rights by the debtor in accordance with Article 10 paragraph 1 of the UUHT. ${ }^{8}$

Bad credit in question is credit that is experiencing repayment difficulties. This can make the bank worse if the amount of bad credit is large. In the event of bad credit, efforts to resolve banking problems in terms of bad credit are broadly grouped into 2 (two) stages, namely the rescue effort stage and the settlement effort stage tends to focus on actions to seek payments, make cash collateral disbursements, collect claims from guarantor, take over collateral. by the bank itself, voluntary sale or sale of collateral by auction ${ }^{9}$. According to Article 20 of Law No. 4 of 1996 concerning Mortgage Rights, the execution of the Mortgage can be carried

3 Arini Sutanti, Anis Mashdurohatun, Perlindungan Hukum Bagi Konsumen Pemberi Agunan Dalam Transaksi Kredit Pada Lembaga Keuangan Bank (Kajian Terhadap Pembebanan Hak Tanggungan), Jurnal Akta, Vol 4 No 4, 2017, Page.677.

4 Dewi Nurul Musjtari, Penyelesaian Sengketa Akad Pembiayaan dengan Jaminan Hak Tanggungan dalam Praktik Perbankan Syariah, Parama Publising, Yogyakarta, 2016, Page.122.

5 Ragga Bimantara, Penyelesaian Kredit Macet Perseroan Melalui Eksekusi Jaminan Hak Tanggungan Atas Nama Pribadi, Jurnal Bina Mulia Hukum, Volume 3 No. 2, Maret 2019, Page. 244

6 Salim. HS, Perkembangan Hukum Jaminan di Indonesia, PT. RajaGrafindo Persada, 2008, Page.6, see to Anis Mashdurohatun dkk, Rekonstruksi Parate Eksekusi Hak Tanggungan Atas Tanah Yang Berkeadilan, Unissula Press, Semarang, Page.12.

7 Benny Riyanto, Marjo, Amanda Happy Diana, Upaya Pembatalan Lelang Eksekusi Hak Tanggungan Akibat Kredit Macet (Dalam Putusan Nomor 113/Pdt.G/2014/Pn.Smg), Diponegoro Law Review, Volume 6 Nomor 1, Tahun 2017, Page.5

8 Sonia Ratulangi Hakim, Skripsi: Pelaksanaan Parate Eksekusi Hak Tanggungan Sebagai Alternatif Penyelesaian Kredit Bermasalah di Bank CIMB NIAGA Semarang, Unissula, Semarang, 2014, Page. 4

9 Dewi Nurul Musjtari, Penyelesaian Sengketa Akad Pembiayaan dengan Jaminan Hak Tanggungan dalam Praktik Perbankan Syariah, Pranama Publising, Yogyakartap. 2016. Page. 179 
out in two ways, namely underhand sales if it benefits all parties and the sale of the object of the Mortgage by auction. ${ }^{10}$

The risk of bad credit still often occurs every month both at Commercial Banks, Sharia Banks and Rural Banks. The amount of nonperforming loans for Conventional Commercial Banks and Sharia Banks nationally in May 2018 was IDR 1,185,000,000, while the amount of bad loans for People's Credit Banks nationally was IDR 3,609,000,000 and for the Central Java region IDR $1,680,000,000 .{ }^{11}$ Meanwhile, at one of the People's Credit Banks in Karanganyar Regency, the amount of credit tied to Mortgages in May 2018 was around 185 accounts with a collateral value of IDR 50,105,428,250 and for bad credit in May 2018 a total of IDR $1,119,527,756$ or around 2.19 percent. . In June 2018, the number of loans tied to Mortgage Rights was around 180 accounts with a collateral value of IDR $49,928,576,250$ and the amount of bad loans in June 2018 IDR $1,104,449,556$ or around $2.12 \%$. Whereas in July 2018 the collateral value of the Mortgage Rights from 183 accounts was IDR 52,412,738,750 and bad credit in July 2018 was IDR $831,744,546 .{ }^{12}$ Based on the data above, at this Rural Bank the risk of bad credit occurs every month.

Bad credit occurs at the Bank either caused by the bank, such as the existence of certain interests of the credit provider officials for requests for inappropriate credit on an unhealthy basis for their customers by expecting rewards from customers, and the bank does not dig up information about financial data and reports. ${ }^{13}$ customer's business. Bad credit can also be caused by the customer himself, such as the customer not being able to allocate borrowed funds so they cannot pay off the debt. ${ }^{14}$ This study aims to analyze the factors that cause bad credit to credit agreements between creditors and debtors and to formulate a model for settling bad loans against credit agreements between creditors and debtors.

\section{B. RESEARCH METHOD}

This research uses an empirical juridical approach, which is an approach by analyzing various normative laws and regulations and analyzing people's behavior related to economic, political, social and cultural aspects. ${ }^{15}$ This type of research is a descriptive study. This research will provide an overview of a symptom or problem of bad credit according to the findings in the field. The data used are primary data and secondary data, data obtained

10 Saryana, Efektivitas Pelaksanaan Undang-Undang Nomor 4 Tahun 1996 Tentang Hak Tanggungan Dalam Pelaksanaan Pemberian Kredit Bank, Hukum Dan Dinamika Masyarakat, Volume 11 No. 2, 2014. Page. 180

11 https://www.ojk.go.id/id/kanal/perbankan/dana-dan-statistik,statistik-perbankan-indonesia accesed on 4th August 2018 at 08:30 GMT

12 Pura Arthakencana Jatipuro, Annual Report of the People's Credit Bank, Karanganyar, 2018.

13 Angga Dwi Prabekti, Fitika Andraini, Faktor-Faktor Penyelesaian Dan Penyelamatan Pinjaman (Kredit Macet) Di Koperasi Artha Sejati Semarang, Dinamika Hukum, Volume 20 No. 1, April 2018, Page. 25-26

14 Zainal Asikin, Pengantar Hukum Perbankan Indonesia, Rajawali Pers, Jakarta, 2015, Page.194.

15 Irwansyah, Penelitian Hukum Pilihan Metode dan Praktik Penulisan Artikel, Mirra Buana Media, Yogyakarta, 2020, Page.176. 
from library materials. ${ }^{16}$ Furthermore, the data were arranged systematically and analyzed descriptively and analytically.

\section{RESULTS AND DISCUSSION}

\section{Factors That Cause Bad Credit To Credit Agreements Between Creditors And Debtors}

Basically, the material agreement can be divided into 2 types, namely the principal and the access agreement. The principal agreement is an agreement to obtain credit facilities from banking institutions or non-bank financial institutions. Accessory agreement is an agreement that is additional in nature and is linked to the main agreement. Examples of accesoir agreements are agreements for the imposition of guarantees, such as pledge, dependents and fiduciary agreements. So, the nature of the guarantee agreement is an access agreement, which is following the main agreement. ${ }^{17}$

Increasing lending is usually accompanied by an increase in nonperforming loans. Although the percentage of the number and the increase is not large, non-performing loans will affect the health of banks. Periodic payments or credit on a financing sometimes cause several problems such as non-performing credit and even bad credit. Not all customers can fulfill their obligations to the bank smoothly or on time ${ }^{18}$. For this reason, banks in providing credit always prioritize a security system, namely assessing potential borrowers from various aspects. ${ }^{19}$ These aspects are better known as the 5 C's principle consisting of the character of the debtor, the capacity or ability of the debtor, capital or debtor capital, collateral or guarantees and the conditions of economic or business prospects of the debtor.

Criteria for Classification of Credit Quality according to Article 12 paragraph 3 of Bank Indonesia Regulation Number 7/2 / PBI / 2005 concerning Asset Qualitad Assessment for Commercial Banks, is divided into 5, namely: ${ }^{20}$

a. Current credit, that is, if it meets the criteria:

1) Payment of principal and / or interest is correct;

2) Have an active account mutation;

3) Part of the credit secured by cash collateral;

b. Credit is of particular concern, that is, if it meets the criteria:

1) There are arrears in principal and / or interest installments that have not exceeded 90 days;

2) Sometimes an overdraft occurs;

3) Relatively low account movements;

16 Zainudin Ali, Metode Penelitian Hukum, Sinar Grafika, Jakarta, 2016, Page. 23-24

17 Jamal Wiwoho, Anis Mashdurohatun, Hukum Kontrak, Ekonomi Syariah dan Etika Bisnis, Undip Press, Semarang. 2017, Page.145.

18 Januar Daningrum, Mikhriani, Metode Penyisihan Piutang Tak Tertagih Pada Produk Qardh Di Bank Pembiayaan Rakyat Syariah Barokah Dana Sejahtera Yogyakarta Periode 2017, Jurnal Bisnis Teori dan Implementasi, Vol. 9 No. 1 : 22-36, Februari 2018, Page.22.

19 Gatot Supramono, Perbankan dan Masalah Kredit, Rineka Cipta, Jakarta, 2009, Page.158.

20 Hermansyah, Hukum Perbankan Nasional Indonesia, Kencana, Jakarta, 2013, Page.66-68. 
4) It is rare for a contract to be violated;

5) Supported by new loans;

c. Credit is substandard, that is, if it meets the criteria:

1) There are arrears in principal and / or interest installments that have exceeded 90 days;

2) Overdrafts often occur;

3) The frequency of account mutations is relatively low;

4) There was a breach of contract that was promised for more than 90 days;

5) There are indications of financial problems faced by debtors;

6) Weak loan documentation;

d. Doubtful credit, that is, if it meets the criteria:

1) There are arrears in principal and / or interest installments that have exceeded 180 days;

2) Often, overdrafts are permanent;

3) There is a default of more than 180 days;

4) There is a capitalization of interest;

5) Weak legal documentation for both credit agreements and collateral engagements.

e. Bad credit, that is, if it meets the criteria:

1) There are arrears in principal and / or interest installments that have exceeded 270 days;

2) The operating loss is covered by a new loan;

3) From a legal perspective as well as market conditions, collateral cannot be cashed at fair value;

According to Supriyadi ${ }^{21}$, Broadly speaking, there are two things that cause bad credit in murābahah financing, namely internal factors and external factors.

The provision of credit with guarantees of mortgage rights at the People's Credit Bank of Pura Arthakencana Jatipuro Regency is not always of good quality. The debtor sometimes defaults, the default means the debtor does not pay or is late in paying predetermined installments. The debtor's negligence in fulfilling its obligations will harm the bank as a creditor. If the debtor is unable to pay off his debt as promised is called bad credit. At the Pura Arthakencana Jatipuro People's Credit Bank, Karanganyar Regency, in the last three years, there were debtors who were in the bad credit category. The data are as follows:

21 Supriyadi, Desain Penyelesaian Kredit Macet Pembiayaan Murâbahah BMT Bina Ummat Sejahtera Melalui Pendekatan Socio Legal Research, $A L-' A D A L A H$, Vol. XIII, No. 2, Desember 2016, Page.195. 


\section{Table of the Number of Bad Loans in a Credit Agreement with a Guarantee of Mortgage at the Pura Arthakencana Jatipuro People's Credit Bank, Karanganyar Regency (2015-2017 Period) $)^{22}$}

\begin{tabular}{llll} 
Year & 2015 & 2016 & 2017 \\
\hline Credit agreement & 4 & 3 & 12 \\
\hline Mortgage right & 4 & 3 & 12 \\
\hline $\begin{array}{l}\text { Outstanding } \\
\text { Credit }\end{array}$ & IDR 110.381 .900 & IDR 36.122.263 & IDR 378.134.953
\end{tabular}

Based on the table, the risk of bad credit still occurs every year, as in 2015 there were 4 credit debtors with collateral as collateral that were included in the bad credit category with a loan value of $\mathrm{Rp}$ $180,000,000$, a mortgage value of $\mathrm{Rp} 270,000,000$ and the remaining loan of Rp 110,381. 900. In 2016 there were also loans with collateral as well as bad credit, namely 3 debtors with a loan value of IDR $130,000,000$, a mortgage value of IDR $195,000,000$ and the remaining loan was IDR $36,122,263$. In 2017, the risk of bad credit increased significantly because there were 12 debtors who were unable to pay their debts according to the credit agreement with a predetermined mortgage guarantee. The value of the loan in 2017 amounted to Rp $816,000,000$, the amount of insurance rights was $\mathrm{Rp} 1,143,500$ and the remaining credit was $\mathrm{Rp} 378,134,953$.

Basically, a problem arises due to several things from various aspects. Likewise, bad credit that occurs at a bank must be due to certain factors. The factors that cause bad credit include: ${ }^{23}$

a. Bank (Creditors)

The occurrence of bad credit can be caused by banks such as:

1) The bank is not careful in analyzing customer character;

2) The bank does not fully understand the customer's business;

3) Fictitious credit involving internal bank employees;

4) The bank is too sure of the customer's ability;

b. Customer (Debtor)

Customers can cause bad credit due to various factors such as: ${ }^{24}$

1) Customer business has decreased;

2) The customer is not good at managing his business;

3) Bank credit is not used according to what is in the credit application;

4) Debt customers in many places;

5) The customer has family problems;

6) Credit "mask" or credit on behalf of, the name of the debtor in the credit agreement is not the one who uses the loan money. ${ }^{25}$

22 Pura Arthakencana Jatipuro, Annual Report of the People's Credit Bank, Karanganyar, 2018.

23 Agung Kurnianto, 2018, Interview, Director of the People's Credit Bank of Pura Arthakencana Jatipuro, August 20th 2018, Karanganyar Regency

24 Hikmah, Pelaksanaan Penyelesaian Kredit Macet Secara Non Litigasi (Studi Di Pt. Bpr Hasa Mitra), Jurnal Cahaya Keadilan, Volume 3 No. 1, April 2015, Page. 10

25 Ni Luh Dery Suanjan, I Ketut Markeling, Penyelesaian Kredit Macet Dengan Jaminan Fidusia Berupa Piutang Fiktif, Kertha Semaya, Volume 4 No. 3, October 2016, Page. 4 
Thus, the factors that cause bad credit at the People's Credit Bank of Pura Arthakencana Jatipuro, Karanganyar Regency include: Internal factors of creditors / banks: Banks are not thorough in analyzing customer character. confident in the customer's abilities. External factors from the Debtor / Customer: The customer's business has decreased, the customer is not good at managing his business, Bank credit is not used according to what is in the credit application and fictitious credit.

\section{Bad Credit Settlement Model Against Credit Agreements Between Creditors and Debtors}

The role of the financial sector in the growth and development of a nation is undeniably very important, including in this case the presence of both conventional and Islamic banks. ${ }^{26}$ The correct and efficient non-performing loan settlement model is the main alternative, in order to maintain bank health stability and provide business capital to the public.

Non-performing loans can be resolved in a credit administration manner, and for loans that are already at the non-performing quality stage, the handling is emphasized through several efforts that are more of a legal institution. Credit administration settlement is as follows ${ }^{27}$ :

a. Rescheduling, namely changes in credit terms concerning the payment schedule and / or the period including the grace period, including changes in the amount of installments or not;

b. Reconditioning, namely changes in part or all of the credit terms which are not limited to changes in payment schedules, time periods, and or other requirements as long as they do not involve changes in the maximum credit balance and conversion of all or part of the loan into bank participation;

c. Restructuring, namely changes in credit terms in the form of additional bank funds; and / or conversion of all or part of the interest arrears into new loan principal, and / or conversion of all or part of the credit into participation in the company.

In 2018, there was also bad credit on loans tied to Mortgage guarantees, from January to October 2018 there were 13 customers who experienced bad credit. ${ }^{28}$ After there is a sign of non-performing credit, against the non-performing loan, the Pura Arthakencana Jatipuro

26 Teguh Yuli Indriyanto, Rusdiah Iskandar, Dwi Risma Deviyanti, Pengaruh debt financing dan equity financing terhadap return on equity pada bank syariah yang terdaftar di bank Indonesia, AKUNTABEL 15 (2), 2018, Page.140.

27 Subagyo, Ahmad, 2015, Teknik Penyelesaian Kredit Bermasalah, Mitra Wacana Media, Jakarta, Page.86-88. Bank Indonesia Regulation No. 8/19 / PBI / 2006, see too the Financial Services Authority Agency made it very clear to all banks, both Islamic banks and conventional banks, so that they can apply the Prudential Principle in carrying out the credit restructuring process for non-performing loans in accordance with the Regulation Financial Services Authority Number II / POJK.03 / 2015 Concerning Prudential Provisions in the Context of National Economic Stimulus for Commercial Banks.

28 Agung Kurnianto, Interview, Director of the People's Credit Bank of Pura Arthakencana Jatipuro, October 5th 2018, Karanganyar Regency, 2018 
People's Credit Bank, Karanganyar Regency will make various efforts to save non-performing loans such as verbally reprimanding the debtor and warning the debtor to carry out the obligation to pay credit installments to return to a smooth credit line.. ${ }^{29}$

In addition, the bank will provide a subpoena to the debtor that contains: ${ }^{30}$

a. Notification regarding the due date of loan principal and / or interest

b. An order to pay a certain amount of debt at the bank's request

c. The time limit for the debtor to make payments.

If after three consecutive orders, the debtor is not in good faith to fulfill his obligations under the credit agreement, then the Arthakencana People's Credit Bank will make rescue efforts in accordance with a Bank Indonesia Circular, namely through: rescheduling, efforts to change the payment schedule. or credit period; reconditioning, changes in part or all of the credit terms which are not limited to changes in payment schedules, time periods, and / or other terms as long as they do not involve changes in the maximum balance; and restructuring, changing credit terms. $^{31}$

The bad credit restructuring provided by the Pura Arthakencana People's Credit Bank consists of: ${ }^{32}$
a. Lower Loan Interest Rates;
b. Reduction of Loan Interest Arrears;
c. Credit Term Extension;
d. Additional Credit Facility;

However, if all the above credit rescue efforts have been taken but the debtor is still unable to pay off the debt, the Arthakencana Jatipuro People's Credit Bank, Karanganyar Regency will handle the problematic credit settlement. Handling non-performing loans can be done by seeking payment by executing collateral through cash collateral disbursement, invoicing to the guarantor, taking over collateral by the bank, selling under hand and selling collateral by auction. ${ }^{33}$

Collateral is generally regulated in Article 1131 of the Civil Code which stipulates that all property rights of a debtor, both movable and immovable, both existing and future ones, are borne by all the engagements. $^{34}$ Thus, all the assets of the debtor are automatically guaranteed when the person makes a debt agreement even though it is not expressly stated as collateral. Collateral is a creditor's need to minimize risk if the debtor is unable to settle all obligations relating to

29 Agung Kurnianto, Loc.Cit.

30 M. Reza Arif Rahman,Penyelesaian Kredit Macet Dengan Jaminan Fidusia Berupa Piutang Fiktif. (Studi Di Pt. Bank Rakyat Indonesia (Persero) Tbk. Cabang Tulungangung), Jurnal Mahasiswa Fakultas Hukum Brawijaya, August 2014

31 Agung Kurnianto, Op.Cit.

32 Agung Kurnianto, Ibid

33 Agung Kurnianto, Ibid

34 Jamillah, Pelaksanaan Pasal 1131 KUHPerdata atas Jaminan Benda Milik Debitur, Mercatoria, Volume 10 No.2, December 2017, Page. 142 
the credit that has been disbursed. With a guarantee that if the debtor is unable to pay, the debtor can force payment for the credit he has given. ${ }^{35}$

Thus, the settlement model for bad credit at a Rural Bank is initiated by giving a verbal summons or warning and a written warning containing notification of payment due dates, orders to pay and notification of deadlines for making payments. ${ }^{36}$ In addition, the Pura Arthakencana Jatipuro People's Credit Bank in Karanganyar Regency will rescue bad debts by means of reschuding, reconditioning, and credit restructuring. If the credit rescue has not been successful, credit handling will be carried out through collateral execution through cash collateral disbursement, billing to the guarantor, take over of collateral by the bank, underhand sales and sale of collateral by auction.

\section{CONCLUSION}

Factors that cause bad credit include: Internal factors from the Creditors / Banks: Banks are not thorough in analyzing customer characteristics. External factors from the Debtor / Customer: The customer's business has decreased, the customer is not good at managing his business, the bank credit is not used according to what is in the credit application, the customer is debt in many places, the customer has family problems, "mask" credit or credit for name, the name of the debtor in the credit agreement not the one using the loan money. The settlement model for bad credit at Bank Perkreditan Rakyat is by giving a verbal summons or warning and a written warning containing notification of payment due, orders to pay and notification of deadlines for making payments. In addition, saving bad debts by means of credit reschudeling, reconditioning and restructuring. If the credit rescue has not been successful, credit handling will be carried out through collateral execution through cash collateral disbursement, billing to the guarantor, takeover of collateral by the bank, underhand sales and sale of collateral by auction.

35 Badriyah Harun, 2010, Penyelesaian Sengketa Kredit Bermasalah, Pustaka Yustisia, Yogyakarta, Page.67.

36 Anak Agung Intan Wulan Sari, Ida Bagus Putra Atmadja, Anak Agung Sagung Wiratni Darmadi, Pelaksanaan Perjanjian Kredit Jaminan Perorangan Terkait Debitur Wanprestasi Pada Bank Perkreditan Rakyat, Kertha Semaya, Volume 3 No. 1, January 2015, Page. 9 


\section{BIBLIOGRAPHY}

\section{Books}

Badriyah Harun, 2010, Penyelesaian Sengketa Kredit Bermasalah, Pustaka Yustisia, Yogyakarta;

Dewi Nurul Musjtari, 2016, Penyelesaian Sengketa Akad Pembiayaan dengan Jaminan Hak Tanggungan dalam Praktik Perbankan Syariah, Pranama Publising, Yogyakarta;

Gatot Supramono, 2009, Perbankan dan Masalah Kredit, Rineka Cipta, Jakarta;

Hermansyah, 2013, Hukum Perbankan Nasional Indonesia, Kencana, Jakarta;

Imron Rosyadi, 2017, Jaminan Kebendaan Berdasarkan Akad Syariah, Kencana, Jakarta;

Irwansyah, 2020, Penelitian Hukum Pilihan Metode dan Praktik Penulisan Artikel, Mirra Buana Media, Yogyakarta;

Jamal Wiwoho, Anis Mashdurohatun, 2017, Hukum Kontrak, Ekonomi Syariah, dan Etika Bisnis, Undip Press, Semarang;

Pura Arthakencana Jatipuro, 2018, Annual Report of the People's Credit Bank, Karanganyar;

Salim. HS, 2016, Perkembangan Hukum Jaminan di Indonesia, PT. RajaGrafindo Persada, 2008, Page.6, see to Anis Mashdurohatun dkk, Rekonstruksi Parate Eksekusi Hak Tanggungan Atas Tanah Yang Berkeadilan, Unissula Press, Semarang;

Sonia Ratulangi Hakim, 2014, Pelaksanaan Parate Eksekusi Hak Tanggungan Sebagai Alternatif Penyelesaian Kredit Bermasalah di Bank CIMB NIAGA Semarang, Skripsi, Fakultas Hukum, Unissula, Semarang;

Subagyo, Ahmad, 2015, Teknik Penyelesaian Kredit Bermasalah, Mitra Wacana Media, Jakarta;

Zainal Asikin, 2015, Pengantar Hukum Perbankan Indonesia, Rajawali Pers, Jakarta;

Zainudin Ali, 2016, Metode Penelitian Hukum, Sinar Grafika, Jakarta;

\section{Journals}

Anak Agung Intan Wulan Sari, Ida Bagus Putra Atmadja, Anak Agung Sagung Wiratni Darmadi, Pelaksanaan Perjanjian Kredit Jaminan Perorangan Terkait Debitur Wanprestasi Pada Bank Perkreditan Rakyat, Kertha Semaya, Volume 3 No. 1, January 2015;

Anis Mashdurohatun., R. Sidji, Gunarto, and Mahmutarom, Factors Causing Banking Cyber Crime in Indonesian. International Journal of Economic Research 14 (15), 2017;

Anis Mashdurohatun, Tantangan Ekonomi Syariah dalam Menghadapi Masa Depan Indonesia di Era Globalisasi, Jurnal Dinamika Hukum, Vol. 11, February 2011; 
Anis Mashdurohatun, Problematika Perlindungan Hak Cipta Di Indonesia, Yustisia, Vol.1 No.1 Januari - April 2012;

Angga Dwi Prabekti, Fitika Andraini, Faktor-Faktor Penyelesaian Dan Penyelamatan Pinjaman (Kredit Macet) Di Koperasi Artha Sejati Semarang, Dinamika Hukum, Volume 20 No. 1, April 2018;

Arini Sutanti, Anis Mashdurohatun, Perlindungan Hukum Bagi Konsumen Pemberi Agunan Dalam Transaksi Kredit Pada Lembaga Keuangan Bank (Kajian Terhadap Pembebanan Hak Tanggungan), Jurnal Akta, Vol 4 No 4, 2017;

Bambang Suprabowo dkk, The Inhibiting Factors On Legal Protection For Recipients Of Fidusiary Warranties With Inventory Guaranted Objects, South East Asia Journal of Contemporary Business, Economics and Law, Vol. 13, Issue 4 (August) ISSN 2289-1560;

Benny Riyanto, Marjo, Amanda Happy Diana, Upaya Pembatalan Lelang Eksekusi Hak Tanggungan Akibat Kredit Macet (Dalam Putusan Nomor 113/Pdt.G/2014/Pn.Smg), Diponegoro Law Review, Volume 6 Nomor 1, Tahun 2017;

Hikmah, Pelaksanaan Penyelesaian Kredit Macet Secara Non Litigasi (Studi Di Pt. Bpr Hasa Mitra), Jurnal Cahaya Keadilan, Volume 3 No. 1, April 2015;

Jamillah, Pelaksanaan Pasal 1131 KUHPerdata atas Jaminan Benda Milik Debitur, Mercatoria, Volume 10 No.2, December 2017;

Januar Daningrum, Mikhriani, Metode Penyisihan Piutang Tak Tertagih Pada Produk Qardh Di Bank Pembiayaan Rakyat Syariah Barokah Dana Sejahtera Yogyakarta Periode 2017, Jurnal Bisnis Teori dan Implementasi, Vol. 9 No. 1 : 22-36, Februari 2018;

M. Reza Arif Rahman,Penyelesaian Kredit Macet Dengan Jaminan Fidusia Berupa Piutang Fiktif. (Studi Di Pt. Bank Rakyat Indonesia (Persero) Tbk. Cabang Tulungangung), Jurnal Mahasiswa Fakultas Hukum Universitas Brawijaya, August 2014;

Ni Luh Dery Suanjan, I Ketut Markeling, Penyelesaian Kredit Macet Dengan Jaminan Fidusia Berupa Piutang Fiktif, Kertha Semaya, Volume 4 No. 3, October 2016;

Ragga Bimantara, Penyelesaian Kredit Macet Perseroan Melalui Eksekusi Jaminan Hak Tanggungan Atas Nama Pribadi, Jurnal Bina Mulia Hukum, Volume 3 No. 2, Maret 2019;

Saryana, Efektivitas Pelaksanaan Undang-Undang Nomor 4 Tahun 1996 Tentang Hak Tanggungan Dalam Pelaksanaan Pemberian Kredit Bank, Hukum Dan Dinamika Masyarakat, Volume 11 No. 2, 2014;

Supriyadi, Desain Penyelesaian Kredit Macet Pembiayaan Murâbahah BMT Bina Ummat Sejahtera Melalui Pendekatan Socio Legal Research, A/-'Adalah, Vol. XIII, No. 2, Desember 2016; 
Teguh Yuli Indriyanto, Rusdiah Iskandar, Dwi Risma Deviyanti, Pengaruh debt financing dan equity financing terhadap return on equity pada bank syariah yang terdaftar di bank Indonesia, Akuntabel, 15 (2), 2018;

\section{Regulation}

Bank Indonesia Regulation No. 8/19 / PBI / 2006;

Financial Services Authority Regulation Number II / POJK.03 / 2015 Concerning Prudential Provisions in the Context of National Economic Stimulus for Commercial Banks;

\section{Internet}

https://www.ojk.go.id/id/kanal/perbankan/dana-dan-statistik,statistikperbankan-indonesia;

\section{Interview}

Agung Kurnianto, 2018, Interview, Director of the People's Credit Bank of Pura Arthakencana Jatipuro, August 20th 2018, Karanganyar Regency; 